\title{
Propose Business Strategy for Coffee Shop in Indonesia (XYZ Company)
}

\author{
Aditia Pramagista and Harimukti Wandebori
}

\section{ABSTRACT}

Indonesia is one of the most potential markets for entrepreneurs who want to enter the coffee shop industry. The phenomenon of coffee as one of the local wisdoms in Indonesia has encouraged XYZ to have a vision of promoting the uniqueness of Indonesian coffee. However, XYZ ran into various hurdles to keep his business. XYZ's performance from early 2018 to early 2020 experienced fluctuating conditions and in early 2020 experienced a drastic decline due to the effects of COVID-19. Then in mid2020, the company started to improve its strategy in dealing with the impact of the pandemic. Currently, XYZ has one store in Tebet, South Jakarta.

This study aims to assist the XYZ team in improving sales performance, especially in marketing strategies. In identifying external problems, this study uses general environmental analysis, industrial environmental analysis and competitor analysis. In identifying internal problems, this study uses resource analysis, value chain analysis, marketing mix analysis and competitor exploration. Furthermore, this study uses a qualitative approach that collects data from interviews with 15 customers as respondents. The respondents who were interviewed had the aim of capturing customer values and XYZ's ability to fulfill customer values. Interviews were also conducted due to changes in conditions caused by the pandemic which are likely to have an impact on customer value.

Based on the analysis and determination of the direction of corporate strategy, this study finds that the company's situation is at the stage of growth and diversification. At this stage, $X Y Z$ needs to prioritize the target market according to its potential. In addition, this study also suggests XYZ to implement a diversification strategy in marketing activities. Finally, this study also uses the TOWS matrix as the main tool for developing marketing activities. In conclusion, this study proposes a strategy map, schedule, activity time and cost estimation as an implementation plan.

Keywords: Business Strategy, Coffee Shop, Small Medium Enterprise.

\section{INTRODUCTION AND RESEARCH OBJECTIVES}

Indonesian coffee shop was growth $8 \%$ in 2018 and forecasted growth $15 \%$ until $20 \%$ until the end of 2019 [1]. Indonesian coffee shop was growth $8 \%$ until $10 \%$ in 2018 and forecasted growth $15 \%$ until $20 \%$ until the end of 2019 (Bisnis.com). Specialty Coffee Association of Indonesia (SCAI) announce those growth absorb $25 \%$ - 30\% coffee local production and increase until $40 \%$ which is in the range of 360.000 until 380.000 tons coffee bean by the end of the 2019. Coffee industry could be considered as a promising business since according ministry of agriculture stated in databoks.katadata.co.id, "2021, Indonesian Coffee Consumption Forecasted Reach 370.000 tons" [2].

Coffee consumption is constantly increasing until forecasted up to 2021 even though from local production perspective there is a significant decreasing from 2018 to 2019 and predicted still going down until 2021. This
Published Online: January 20, 2021

ISSN: 2507-1076

DOI: $10.24018 /$ ejbmr.2021.6.1.687

Aditia Pramagista *

Institut Teknologi Bandung, Indonesia.

(e-mail: aditia.pramagista ${ }^{\circledR}$ sbm-itb.ac.id) Harimukti Wandebori

Institut Teknologi Bandung, Indonesia.

*Corresponding Author condition become an opportunity for coffee maker especially for Small Medium Enterprise (SME) which dominant the market.

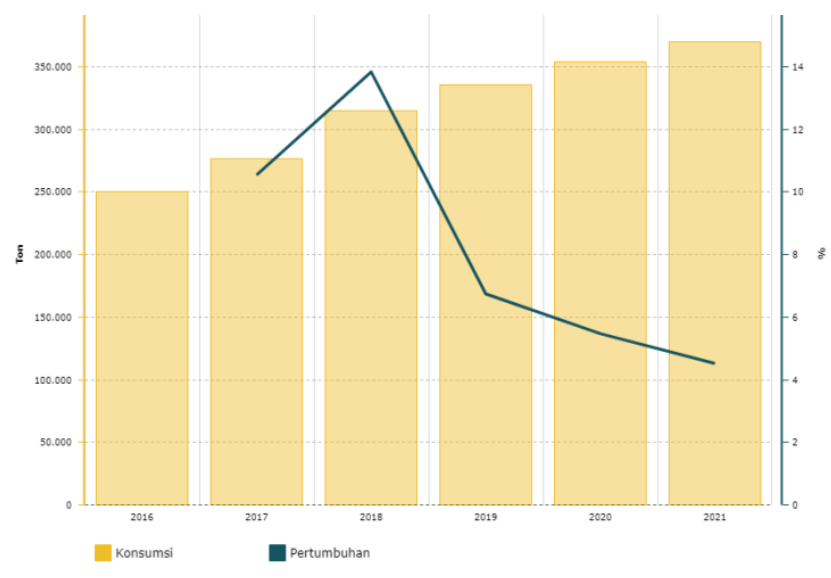

Fig. 1. National Coffee Consumption. 


\section{A. Statement of the Problem}

The problems appear when the founders evaluate the current processes and end up with set the revenue target in 20 million in the minimum in order to cover all the costs and as a breakeven point in monthly basis. Sales performances are tend to fluctuated and some months are near to BEP which is need to be analyzed and put more concern on the performance evaluation to overcome revenue decreasing. Some strategies have been planned and will be executed on 2020 but unfortunately the pandemic arise and all the strategies need to be adjusting since everything has been changed. XYZ team should solve the decreasing performance that happened in order to survive during and after pandemic. Set the priority and appropriate strategy for adjustment concepts with minimal historical concept experience and the long-term strategy after pandemic become a main business issue of this research.

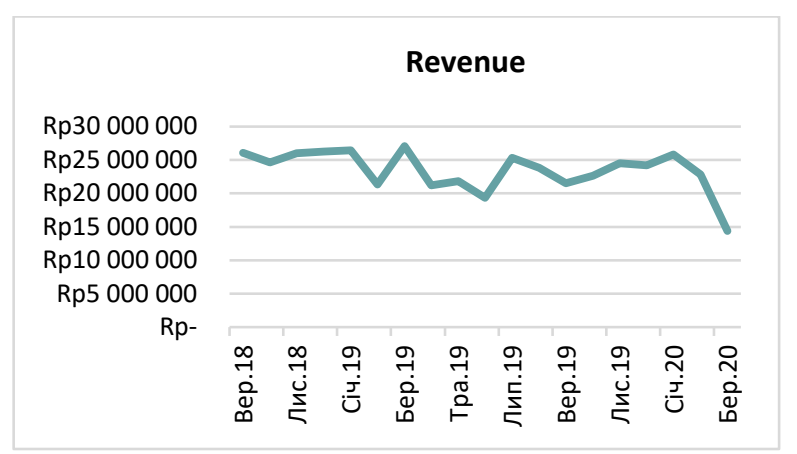

Fig. 2. XYZ's Revenue.

\section{B. Research Objective}

Exploring and adjusting current strategy in pandemic situation and to design the best strategy after pandemic effect to increase revenue according to the company condition.

\section{ReSEARCH Methodology}

TABLE 1: RESEARCH CHARACTERISTIC

\begin{tabular}{ccc}
\hline No & Research Characteristics & Type \\
\hline 1 & Method & Qualitative \\
2 & Purpose of Study & Descriptive \\
3 & Type of Investigation & Correlational \\
4 & Extent of Researcher & Minimal interference \\
5 & Interferences & Individual \\
6 & Unit of Analysis & Cross sectional \\
\hline
\end{tabular}

The author conducting qualitative approach whereas the study is focusing on small numbers of individuals in certain situations and preserves the individuality of each of these in the analyses, especially in the pandemic situation that never faced before.

\section{EXTERNAL ANALYSIS}

External analysis is aiming for analyzing the circumstances of XYZ in the research that have an impact and correlation with business issue. External analysis also conducted in order to summarize the opportunities that arise for the business and the possibility of threat that can impact to the business [13]. Simply, external analysis is aiming for determine the future possible condition from the circumstances.

\section{A. General Environment Analysis}

On this stage, the author tries to analyze the macrocondition that affects XYZ's business. Demographic, Economic, Political/Legal, Sociocultural, Technological and Physical aspects are considered that could give an impact on all business activities.

\section{- Demographic Aspect}

Demography is the study of human populations in terms of size, density, location, age, gender, race, occupation, and other statistic. XYZ currently have one store located in South Jakarta, specifically in Tebet area. As an SME in F\&B business, focusing on current circumstances is important in order to keep the business sustain and efficient.

TABLE 2: POPULATION SIZE IN SOUTH JAKARTA

\begin{tabular}{ccccc}
\multicolumn{5}{c}{ TABLE 2: POPULATION SIZE IN SOUTH JAKARTA } \\
\hline Age groups & 2017 & 2018 & 2019 & 2020 \\
\hline $0-4$ & 192.676 & 189.257 & 185.452 & 181.325 \\
$5-9$ & 190.072 & 194.229 & 196.829 & 197.128 \\
$10-14$ & 160.528 & 163.495 & 167.441 & 173.041 \\
$15-19$ & 145.833 & 147.306 & 149.163 & 150.827 \\
$20-24$ & 166.159 & 159.346 & 153.434 & 148.835 \\
$25-29$ & 207.348 & 199.933 & 192.075 & 184.332 \\
$30-34$ & 221.061 & 219.303 & 217.116 & 214.551 \\
$35-39$ & 209.790 & 212.838 & 215.279 & 216.322 \\
$40-44$ & 183.370 & 187.810 & 192.031 & 196.388 \\
$45-49$ & 154.620 & 158.482 & 162.388 & 166.350 \\
$50-54$ & 125.607 & 129.685 & 133.777 & 137.837 \\
$55-59$ & 98.347 & 102.300 & 106.308 & 110.510 \\
$60-64$ & 71.793 & 76.043 & 80.203 & 84.157 \\
$65-69$ & 47.744 & 51.117 & 54.743 & 58.590 \\
$70-74$ & 28.203 & 29.947 & 31.940 & 34.237 \\
$75+$ & 23.679 & 25.046 & 26.520 & 28.091 \\
Total & 2.226 .83 & 2.246 .13 & 2.264 .699 & 2.282 .521 \\
\hline
\end{tabular}

The data shows the potential population in South Jakarta during last four years is considered into three categories which is 25-29, 30-35 and 35-39. Based on location, XYZ located in Tebet South Jakarta with complexly surrounded by business district and private residence. There are many groups of people with various value and interest available to be served by XYZ. XYZ just need to prioritize a certain group of consumer which have same objectives with $\mathrm{XYZ}$ businesses.

\section{- Economic Aspect}

SMEs also playing as an important role since counted more than 98 percent of business activities in Indonesia running as micro business. We can conclude that SME is playing an important role on Indonesian Economic Growth [3]. However, pandemic effect really hits economic sector negatively and impact to the business ecosystem. There are three main effects that caused by pandemic; consumption has a decreasing value from 5,02 percent to 2.84 percent on the first quarter, the uncertainty affects the decreasing of investment and implicates to the bankruptcy of many businesses and also the weak of economic sector affects the decreasing of commodity across Indonesia and across the world[4]. With this condition the decreasing of economic growth actually become an opportunity for the SME especially XYZ since many businesses with a higher valuation get bankrupt and all business players need to 
adjust their operation and it became an advantage for XYZ to overtake the competitor who higher valuation.

\section{- Political/Legal Aspect}

Political factor is everything related with government regulation that effect business activities and consist of laws, pressure groups and government agencies. All of which exert some sort of influence and constraint on organization and individuals in society [5]. However, pandemic regulation affects business activities, since according to Ministry of Health Regulation No. 9/2020 about large-scale social restriction (PSBB) in order to accelerate pandemic handling. PSBB is implemented by dismissing school and workplaces, restrictions on religious and public activities. SMEs need to put a concern on this temporary regulation and translate into products and services offered [6].

By several political and regulation condition that currently happened in Indonesia, the effect is really impactful to the XYZ business. Current business operation including value offered by XYZ cannot be smoothly presented since restricted by Health Protocol. And it can be a threat if XYZ cannot capture the new behavior in pandemic era and affects to business performance.

\section{- Sociocultural Aspect}

Drinking coffee and tea become a habit in Indonesia. All consumers across gender and age are drinking both coffee and tea either morning, afternoon and by within their groups or also possibly by him/herself. The most coffee drinker is from Jakarta by 57 percent of the population. Based on frequency, 21 percent of people drink coffee one cup per day and 10.5 percent usually drink coffee two until three cups a day, 4.5 percent for four until five cup a day and there are more than 5 cups a day by 3 percent [7].

By looking from sociocultural aspects, $\mathrm{XYZ}$ business is really promising and has a huge opportunity for the long term business since the habit and the trend of coffee consumption is complementing to other activities.

\section{- Technological Aspect}

Technology environment are forces that create new technologies, creating new product and market opportunities. The technological environment is changing rapidly. Marketers should watch the following trends in technology [8]. Currently, the use of technology is able to help around 442.000 SMEs in enhancing business performance that supported by technology provider company [9]. During this pandemic, Go Food services has an increasing performance by twenty percent and it caused people tent to more consuming food and drinks and also have an impact to the product or service package offered that should be served by the business owners [10]. From Technological perspective, the development of application really have an good impact to the promoting and reaching various segment of end-consumer which can conclude that $\mathrm{XYZ}$ business have an opportunity in the rapid development of technology.

\section{- Physical Aspect}

Physical aspect on coffee industry is related with the raw materials of product and services offered by XYZ. There are two types of coffee that have a high demand compare to other category; Arabica and Robusta [11].
TABLE 3: COFFEE CHARACTERISTIC

\begin{tabular}{ll}
\hline \multicolumn{1}{c}{ Arabica } & \multicolumn{1}{c}{ Robusta } \\
\hline Fruity \& Herb Taste & Biter and Sour Taste \\
Light & Heavy \\
Can only grow to a certain height & No minimal height required \\
Does not cause disruption to sleep & Cause disruption to sleep rhythm \\
rhythm & and heart beat \\
Caffeine approximately $1.2 \%$ & Caffeine more than 1.2\% \\
\hline
\end{tabular}

Indonesia as a tropical country have a big opportunity to develop an original taste of coffee based Geographical Indication (GI). GI could come from environment and/or people intervention and have a certification of authenticity and protected by law. Indonesia currently has recorded 17 GI which dominate by Arabica and Robusta criteria across all location in Indonesia [11].

However, pandemic affects the coffee bean production since the health protocol affects the farming processes. Corona virus impact to the decreasing of coffee production up to 35 percent compare to the previous year [12], and it can impact to the XYZ that currently have a competitive advantage on the specialty of coffee bean and tea leaf.

\section{B. Industry Environment Analysis}

Industry Analysis will be conducted by using Porter's five forces, which are Threat of New Entrants, Bargaining Power of Buyers, Bargaining Power of Suppliers, Threat of Substitutes and Intensity of Rivalry among Competitors. The conclusion from this analysis is the higher the forces from each variable, the lower potential profit that can be gain by the company in the industry.

TABLE 4: THE SUMMARY OF PORTER's FIVE FORCES ANALYSIS

\begin{tabular}{llc}
\hline & \multicolumn{1}{c}{ Factors } & Implication \\
\hline Threat of New & - Capital Requirement (Medium) & High Threat of \\
Entrants & - Product Differentiation (Low) & New Entrants \\
& - Technology Requirement & \\
& - Skills Requirement (Medium) & \\
Bargaining Power & - Product Differentiation & High \\
of Buyers & (Medium) & Bargaining \\
& - Switching cost (Low) & Power of \\
& Buyers \\
Bargaining Power & - Search of information (High) & Medium \\
of Suppliers & - Suppliers options (Medium) & Bargaining \\
& - Pandemic effect (High) & Power of \\
& - Switching cost (High) & Suppliers \\
Threat of & High Threat of \\
Substitutes & Access to substitute product & Substitutes \\
& - Competitive Intensity (High) & High Intensity \\
Intensity of & - Industry Growth (High) & of Rivalry \\
Rivalry among & Pumber of competitors (High) & among \\
Competitors & Competitors \\
& (Medium) & \\
& &
\end{tabular}

\section{Competitor Analysis}

In competitor analysis, XYZ has many direct competitors who have a same target market in Tebet area with a similar internal capability. The result of competitor analysis is some competitors have a better competitive advantage to be offered to the market segment. 


\section{INTERNAL ANALYSIS}

Internal analysis is the activities that aim to determine organization current performance and to mapping the possibility of strengths and weaknesses [13]. Basically, there are two approaches that need to be analyze in internal analysis; resources analysis and value chain activity. After analyzing one at a time, it need to be analyzed both together in the functional level since core competencies appear when both resources and value chain are work together on the field.

Resource analysis consists of analyzing tangible and intangible resources [13]. Tangible resources constructed from financial, organization, facility and technology. For financial resources, XYZ have a limitation of capital funding since the company only depend on co-founders which consist of 4 people. The initial capital funded equally by co-founders. The company considered not to find external investors in consideration want to create and establish a good performance and portfolio of the business at the beginning. In term of organization, XYZ as an SME have a simple organizational structure with an effective and efficient number of members. In term of facility, XYZ have a strategic location and have various type of potential consumer to be served. However, located in a strategic location also have an impact on space availability and rental cost. Since XYZ is a SME business, the company has a limitation in providing a bigger space. Company need to prioritize the consumer segment. Current segment priority is to focus on facilitating hangout purposes. In term of technology, company has good supporting tools for coffee processor as main products. Intangible resources consist of human resource, innovation, and reputation. Human resource is related to the knowledge, hard skills and soft skills needed in the business [13]. Managerial team of XYZ has an experience in running the business and coming from management study. For the operational team, the company injects manpower from experience in coffee maker which indicates all the knowledge and necessary skills already shaped in a team. Innovation in the company still needs an improvement because they lack of product innovation and marketing innovation. Reputation of the company can be captured from consumers' perspective. From current performance the stakeholders stated that there are no complaints received by company, which indicates there are no unsatisfying products and services offered by company.

Analyzing value chain will allow company to have a deep understanding to every function in all activities related with having a value creation or not [14]. Value chain consists of primary and support activities. In this research, primary activities consist of inbound logistic, operations, outbound logistic, marketing and sales and service. Inbound logistic includes with maintaining relationship with existing relationship and finding the potential suppliers. Since the company menus is still have a many room of innovations, finding the new various suppliers especially for coffee and tea expert is necessary to be focused. Operation includes all the raw material process preparations such us preparing all the necessary tools, plate and glass, packaging and facility required such us electricity. XYZ have a competitive advantage by offers a periodic product depend on the availability of the materials. Some products need to be adjusting with the packaging to be served and the food processor especially for coffee and tea. After receiving the supply, the team will determine the necessary storage which suitable with the materials. The team will ensure all the materials properly kept and hygiene. Outbound logistic cover the delivery activities to the outlet and delivery the end products for delivery-order consumers. All the distributions activities need to be considered by the time consumed which will impact to the food quality. Company try to cooperate with online delivery platform to reach more consumers who didn't come for dine-in. all the delivery services are running well and also collaborate in create promotion program with online platform to enhance the online purchase and engagement. Marketing and Sales activities are focuses on informational relationship between the managerial team and the operational team. The activity includes the pricing and the engagement program that need to be executed by company. XYZ still lack of marketing activities, especially through online platform. Instagram as XYZ's main social media doesn't utilize effectively to engage more consumers. Inconsistency in executing the strategy can be seen on the program and media used to execute the strategy. Service function become vital for the company since it's responsible for determine all the activities required for fulfill consumer needs in an effective and efficient way. SOP is needed to be designed and all the team follows the SOP. The SOP includes platting design, consumer service and the layout and space used during service time. Currently company focus on serving dine-in consumer meanwhile pandemic effect cannot allow dine-in in with a full of people. XYZ need to adjust strategy with the current situation since the current strategy is not match with the condition.

Support activities are consisting of firm infrastructure, human resource management, technology development and procurement. In term of infrastructure, operational team focuses on the availability of facility which becomes the compliment of the products. Some consumers also expect the availability of facilities become an equal with the product offered. However, company still needs many improvements for facilities to fulfill consumer values. Pandemic also impact to the adjustment of facilities so that the facilities still become the beneficial for company and have a competitive advantage to attract the consumer. Human resource management is responsible in managing manpower needed and the skillset required for each of the function. Financial controlling also taken by this function in order to adjust the skills and the number of people needed with the financial position. Current problems is focus on the decreasing sales performance, team performance still have a good performance which can be seen through compliment received from consumer who dine-in in store. Company's technology development is focus on providing the necessary facility to fulfill consumer values and also for the food processor. Company need to improve their food processor in order to develop various menus especially for food which currently still lack of options. In term of coffee and tea processor, the company already has enough tools to fulfill consumers' need. Procurement function is responsible for ensuring the availability of the materials in the outlets including the incremental equipment. All the spare part 
performance will be recorded and change periodically based on the depreciation time.

\section{SWOT ANALYSIS}

SWOT Analysis conducted after collecting internal and external analysis of XYZ's business activities and finding out the competitive position. Strength and Weakness are summarizing from external condition and Opportunity and Threat are examined from internal condition.

TABLE 5: SWOT ANALYSIS

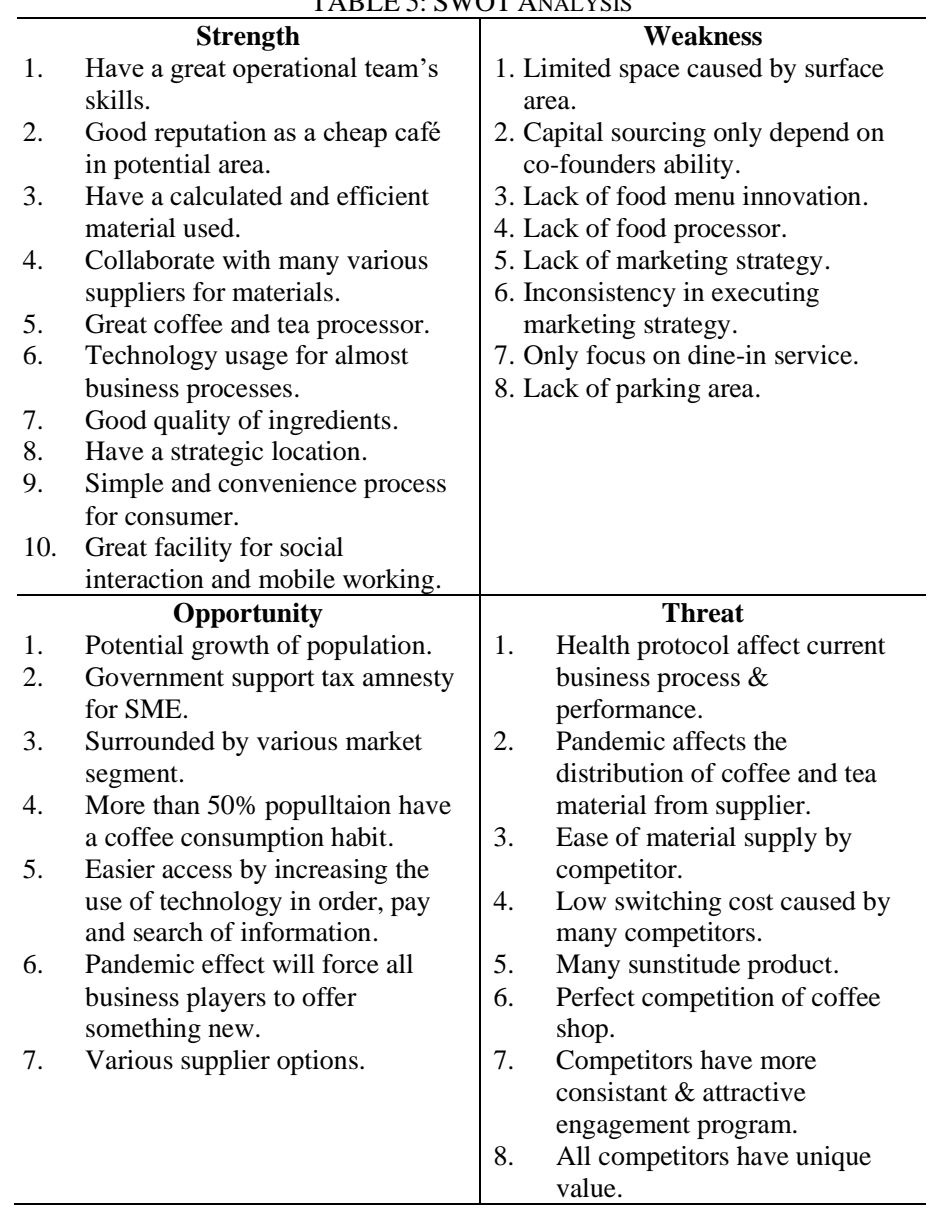

\section{Alternative Solution}

Strategy based on hierarchy divided into 3 layers; corporate strategy, business strategy and functional strategy [13]. After conducting external and internal analysis, growth strategy is chosen since strength and opportunity slightly have more points compare to weakness and threat in XYZ industry. Diversification strategy also needs to be developed by XYZ because strength and threat have more points compare to opportunity and weakness. Both strategies also conducted if we considering the sales performance that need to be boosted so XYZ can survive in pandemic era and after pandemic. In designing corporate strategy, the researcher also consider based on GE metrics. GE metrics consist of business strength factor and industry attractiveness which both factors has been analyzed in external and internal analysis [13]. From business strength, variable consist of; market share, profitability, innovation and brand. The entire variable considered weak since company's market is still small and many competitors appear in surrounding area. Profitability is become the main issue of this research and company still lack of innovation especially for marketing activities. It can be seen from marketing mix analysis, company still have many room of improvement. Brand recognition also still low compare with many competitors since lack of marketing strategy executed by XYZ. By those conditions, it creates business strength of $\mathrm{XYZ}$ considered in the low quadrant. For industry attractiveness, it can be put on high quadrant since the positive growth and the perfect competition indicates the industry is really attractive. Based on the position, the suitable strategy for XYZ are Build selectively, specialize around limited strengths and seek ways to overcome weaknesses.

\section{TOWS MATRIX}

Functional strategies are arranged according to the set of strategies that XYZ want to execute. Several options are summarized from the TOWS matrix (Table 6).

\section{PROPOSED STRATEGIES}

\section{A. Product and Service Development}

Products and services are definitely become the core of business strategies. There are several focus on development direction related to the new business strategy and considered to be executed as soon as possible, as follows:

- Should develop several food options, especially for a heavy meal. It's a must to be executed since XYZ would like to pivot into Co-Working concept and people who spent in a long time need heavy foods. It also considered since most of consumer value that haven't fulfilled by the $\mathrm{XYZ}$ is regarding food menus.

- In term of services and facilities, XYZ need to redesign its layout into more comfort for working space. This kind of market segment is the most possible segment to be served in this pandemic era.

- Develop packaging and adjust the quantity for readyto-go package. This is necessary to be executed since the increasing of online food is exponentially during pandemic.

- Design an attractive food menu for both physically for offline store and for online platform in instagram. Food menus are a necessary to publish on instagram to enhance the possibility of consumer engagement.

- Bundling package is suggested to XYZ in order to attract consumer to bring their relatives in visiting XYZ. It's not limited to be serving through online. The purpose of bundling package is to solve consumers' focus on price sensitive. It also aiming for consumer to be able to share their orders with friends so that they can save some monetary cost. This package is suitable for those who love to share their orders to their relatives.

- Loyalty program also suitable to be executed for the consumers who prioritize their personal value in visiting the storei. The more consumers come, the more benefits they will get in the future. This package is suitable for those who tend to come alone or for mobile working purposes. This program will attract consumer to do repeat order and working from XYZ's store. 


\section{\begin{tabular}{l|l} 
TOWS Matrix & Strength \\
(S1) Have a great operational team's skills
\end{tabular}}

\section{Opportunity
(O1) Potential growth of population}

(O2) Government support tax amnesty for SME

(O3) Surrounded by various market segment (O4) More than $50 \%$ populltaion have a coffee consumption habit

(O5) Easier access by increasing the use of technology in order, pay and search of information

(O6) Pandemic effect will force all business players to offer something new

(O7) Various supplier options

$$
\text { Threat }
$$

(T1) Health protocol affect current business process \& performance

(T2) Pandemic affects the distribution of coffee and tea material from supplier

(T3) Ease of material supply by competitor

(T4) Low switching cost caused by many

competitors

(T4) Many substitude product

(T5) Perfect competition of coffee shop

(T6) Competitors have more consistant \& attractive engagement program

(T7) All competitors have unique value
(S2) Good reputation as a cheap café in potential area

(S3) Have a calculated and efficient material used (S4) Collaborate with many various suppliers for materials

(S5) Great coffee and tea processor

(S6) Technology usage for almost business

processes

(S7) Good quality of ingredients

(S8) Have a strategic location

(S9) Simple and convenience process for consumer

(S10) Great facility for social interaction and mobile working

\begin{tabular}{c|c} 
SO Strategy & WO Strategy \\
$(\mathrm{S} 1, \mathrm{~S} 2, \mathrm{~S} 3, \mathrm{~S} 4, \mathrm{~S} 8, \mathrm{~S} 10, \mathrm{O} 1, \mathrm{O} 2, \mathrm{O} 3, \mathrm{O} 4, \mathrm{O} 5, \mathrm{O} 6$, & $(\mathrm{W} 1, \mathrm{~W} 2, \mathrm{~W} 7, \mathrm{~W} 8, \mathrm{O} 1, \mathrm{O} 3, \mathrm{O} 4, \mathrm{O}$
\end{tabular}

(S1, S2, S3, S4, S8, S10, O1, O2, O3, O4, O5, O6, (W1, W2, W7, W8, O1, O3, O4, O5, O6)

Expand products and services for dine-in consumer value

(S1, S2, S3, S4, S7, S8, O1, O2, O3, O4, O5, O6)

Collaborate with offices to do B2B Market public transportation

(W3, W4, W7, O1, O2, O3, O5, O6, O7) variance
Weakness
(W1) Limited space caused by surface area

(W2) Capital sourcing only depend on co-founders ability

(W3) Lack of food menu innovation

(W4) Lack of food processor

(W5) Lack of marketing strategy

(W6) Inconsistency in executing marketing strategy

(W7) Only focus on dine-in service

(W8) Lack of parking area

Improve several treatment for consumer who used

Add more variant of product especially for food

(W1, W2, W5, W6, W8, O1, O3, O4, O5, O6, O7)

Enhance online and offline engagement program

ST Strategy

(S1, S2, S3, S7, S8, S9, S10, T1, T2, T3, T4, T5,

$\mathrm{T} 6, \mathrm{~T} 7)$ Various promotion program

(S2, S3, S4, S5, S7, T1, T2, T4, T5, T7)

Turnaround strategy by limiting the visitors with special product and services

(S1, S2, S3, S4, S6, S8, S9, S10, T1, T2, T4, T5,

T7)

Pivot products and services

\section{WT Strategy}

(W1, W2, W3, W4, W5, W6, W7, W8, T1, T2, T3, $\mathrm{T} 4, \mathrm{~T} 5, \mathrm{~T} 6)$

Develop ready-to-go products

(W1, W4, W5, W6, W7, W8, T1, T2, T5, T6, T7)

Enhance collaboration with delivery services

(W2, W3, W4, W5, W6, W7, T1, T2, T3, T4, T5,

T6, T7)

Offers product which only presented by Carani with common ingredients.

\section{B. Revenue Stream}

Another revenue stream could be executed by XYZ through targeting a group of consumers that work in Tebet area. In order to solve consumer problems, who need effort to choice what they want to eat and drinks during work hours, XYZ could over and take the opportunity by periodically serve them buy create several group package to the consumer. By providing this package, many advantages will be got by consumer such us time efficiency in ordering food, lower price compare to regular orders and customize menus depend adjusted with consumer needs and XYZ's availability

\section{Social Media Engagement}

In order to enhance social media engagement; especially on Instagram, XYZ could do collaboration with several influencers that have a similarity with XYZ's market segment. XYZ need to pay attention on the engagement rate and activities with their followers since there are also many influencers that don't have many interactions with their followers.

Marketing team also suggested to advertise through Instagram advertisement. The ads will appear in several placements in Instagram feed or stories of targeted consumer. XYZ could focus the content promotion through images or videos and also able to customize several parameters based on demographic, age, gender, interest and behavior. By the respondent background, XYZ could set their focus on millennial workers who are located in south Jakarta and several communities near from south Jakarta.

To executed all the strategies and create the timeline, first thing than need to be done is to set a certain theme on Instagram. Choosing certain pattern, color and set of captions is necessary to design a clean, tidy and presentable content.

\section{CONCLUSION}

Based on the two years performance, XYZ have a decreasing performance due to pandemic effect. Almost all of strategies that has been designed and executed are not running well in pandemic situation and it leads to the decreasing performance in 2020. Researcher is try to evaluate the strategy and adjust to the current condition by try to exploring deep deeper related to consumer value and adjust with the XYZ's availability in fulfilling it. Researcher conducts external and internal analysis which consists of general environment, industry environment, and competitor for external analysis and STP and marketing mix for internal analysis. Consumer exploration also focus on capturing consumer value and finding the deep reason in related value which also considered as internal analysis.

This research using qualitative approach in collecting data based on several questions regarding consumer value exploration. The respondents are the consumer of XYZ with 
total 15 respondents. The respondents are interviewed with several questions and every key point of respondents is confirmed to another respondent until the information are saturated. The value exploring end up with several value that mapped into several categories, and the first dominant value is cannot be served during the pandemic effect that concern on health protocol. So, several adjustment strategies proposed in order to overcome the decreasing of business performance.

\section{REFERENCES}

[1] Ekonomi Bisnis (2020) Industiy kedai kopi ditaksir tumbuh 20 persen tahun ini. Available https://ekonomi.bisnis.com/read/20190822/12/1139918/industrikedai-kopi-ditaksir-tumbuh-20-tahun-ini.

[2] Katadata (2020) Konsumsi Kopi Indonesia Diprediksi Mencapai 370 Ribu Ton. Available https://databoks.katadata.co.id/datapublish/2018/07/31/2021konsumsi-kopi-indonesia-diprediksi-mencapai-370-ribu-ton.

[3] UMKM.id (2020) Kontribusi umkm dalam roda perekonomian Indinesia. Available at: https://umkm-id.com/post/kontribusi-umkmdalam-roda-perekonomian-indonesia.

[4] Republika (2020) Tiga Dampak Besar Pandemi Covid19. Available at: https://republika.co.id/berita/qdgt5p383/tiga-dampak-besarpandemi-covid19-bagi-ekonomi-ri.

[5] Wilson, Richard. (2005), Strategic Marketing Management, MA: Elsevier. 3rd Edition.

[6] Kementrian Kesehatan (2020) Pedoman Pembatasan Sosial Berskala Besar Dalam Penanganan COVID-19. Available at: http://hukor.kemkes.go.id/uploads/produk_hukum/PMK_No_9_Th_ 2020_ttg_Pedoman_Pembatasan_Sosial_Berskala_Besar_Dalam_Pen anganan_COVID-19.pdf.

[7] Republika (2020) Bukti Kopi Sudah Jadi Gaya Hidup Masyarakat Indonesia.

Available

at: https://republika.co.id/berita/py0gka328/bukti-kopi-sudah-jadi-gayahidup-masyarakat-indonesia.

[8] Kotler, Philip. (1996), Principles of Marketing, Essex: Pearson. 4th Edition.

[9] Liputan6 (2020) Peran Teknologi Tumbuhkan Lebih Dari 442 Ribu UMKM. Available https://www.liputan6.com/news/read/3631651/peran-teknologitumbuhkan-lebih-dari-442-ribu-umkm.

[10] Antara News (2020) GoFoof CatatPengingkatan Transaksi 20 Persen pada Masa Pandemi. Available at: https://www.antaranews.com/berita/1579982/gofood-catatpeningkatan-transaksi-20-persen-pada-masa-pandemi.

[11] Sudiarto (2017). Peluang Usaha IKM Kopi. Jakarta: Kementrian Perindustrian.

[12] Katadata (2020) Dampak Pandemi Pemerintah Prediksi Produksi Kopi RI Anjlok 35 Persen. Available at: https://katadata.co.id/ameidyonasution/berita/5f2a902f29d51/dampakpandemi-pemerintah-prediksi-produksi-kopi-ri-anjlok-35.

[13] Wandebori, H., (2019), Manajemen Strategi Dalam Perspektif Indonesia, Bandung, INA: ITB Press.

[14] Hitt, Ireland, and Hoskisson. 2015. Strategic Management: Competitiveness and Globalization (Concepts and Cases). 11th edition. USA: South-Western Cengage Learning.

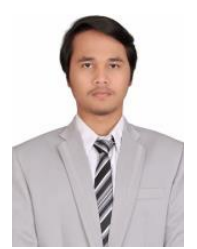

Aditia Pramagista was born in Kabanjahe, July 27, 1996 and he was graduated from Telkom University, Bandung-Indonesia in 2018 majoring Management Studies. He currently pursues Master degree majoring Business and Administration in School Business and Management at Institut Teknologi Bandung, Indonesia.

Research topic that has been carried out are related to consumer exploration, diffusion of innovation, technology adoption and business strategy.

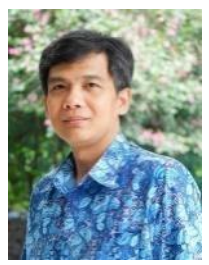

Harimukti Wandebori earned his undergraduate in majoring in electrical engineering at Institut Teknologi Bandung, later $\mathrm{He}$ continued his postgraduate in Maastricht School of Management to get Master in Business Administration, and Doctor in management at University of Twente, Netherlands. $\mathrm{He}$ is an assistant professor of Business Strategy and Marketing Interest Group who has a research interest in strategic management at School of Business and Management, Institut Teknologi Bandung (SBM-ITB). 